\title{
A Update of Archaeological Investigations at the Tyson Site
} (41SY92)

Tom Middlebrook

Heritage Research Center, Stephen F. Austin State University

Follow this and additional works at: https://scholarworks.sfasu.edu/ita

Part of the American Material Culture Commons, Archaeological Anthropology Commons, Environmental Studies Commons, Other American Studies Commons, Other Arts and Humanities Commons, Other History of Art, Architecture, and Archaeology Commons, and the United States History Commons

Tell us how this article helped you.

This Article is brought to you for free and open access by the Center for Regional Heritage Research at SFA ScholarWorks. It has been accepted for inclusion in Index of Texas Archaeology: Open Access Gray Literature from the Lone Star State by an authorized editor of SFA ScholarWorks. For more information, please contact cdsscholarworks@sfasu.edu. 


\section{A Update of Archaeological Investigations at the Tyson Site (41SY92)}

Creative Commons License

(c) (i) (8)

This work is licensed under a Creative Commons Attribution-NonCommercial 4.0 International License 


\section{AN UPDATE OF ARCHAEOLOGICAL INVESTIGATIONS \\ AT THE TYSON SITE (41SY92) \\ by}

Tom Middlebrook

\section{INTRODUCTION}

In recent years, much of the research concerning prehistoric and historic Caddoan lifeways has focused on socio-political organization and community structure. Models have been proposed to predict the character of the archaeological record based on European observations of Caddoan life during the 17th-19th centuries. A brief review of these models is warranted to provide the necessary background for interpreting the results of recent archaeological work at an interesting 15th century site in Deep East Texas.

Story and Creel (1982) have developed an integrative model to describe Hasinai Caddo "settlement patterns, socio-political organization, and intergroup interactions" based on ethnographic and archaeological data. The smallest component within their model was the layout of individual hamlets, with these being integrated into communities (as exemplified by the Deshazo Site). A number of these individual settlements --along with short-term use sites, community cemeteries, and a lesser political/ritual center (e.g., the residence of the caddi or village headman)-- reflected a "constituent group" in the next level of group organization.

These constituent groups, perhaps located within a single drainage basin, were thought to have the highest degree of social identification and interactions. Several constituent groups along with a major center (e.g., residence of the spiritual leader, the xinesi, and the temple) within a larger region composed an "affiliated group." This model attempts to correlate the archaeological findings at small dispersed Caddoan farmsteads and hamlets in East Texas with the ethnohistoric accounts of early Spanish missionaries describing the village life and weak social hierarchy amongst Hasinai groups. 
An example of a "constituent group" may be illustrated in Don Domingo Terán de los Rios' 1691 map of an upper Nasoni village along the Red River. This graphic representation of a Caddoan community has been associated with ethnohistoric data and archaeological findings from the Hatchel-Mitchell-Moores site locality in Bowie County, Texas (Wedel 1978; Perttula 1992; Creel 1993). The map displayed the location of 23 dispersed hamlets and farmsteads containing one or two houses, ramadas, and aboveground beehive structures. On the western edge of the community was a temple atop a mound. Two structures to the east may have represented the residence of the caddi. Comparisons have been made between the Terán map and Cedar Grove (Schambach 1982; Trubowitz 1984) and Roitsch-Williams sites (Bruseth and Perttula 1991).

Wyckoff and Baugh (1980) carefully reviewed Spanish and French ethnographic references to present a predictive model of material culture expected to be found associated with Hasinai governing elites. Their research suggested, for example, that the residence of a caddi would likely be located "near the center, of each inhabited watershed" on "a partially isolated site of approximately 2 to 3 acres." This "residence complex" would be composed of a large house for the caddi (perhaps 60 feet or 18 meters in diameter), a similar sized guest house for assembled canahas (subordinate headmen or village elders), a smaller attendants' house, a plaza and ceremonial area, arbors and middens, and a nearby cemetery. The caddi's house was predicted to be circular in shape, have an eastern entryway and central hearth, have postholes in half of the floor space (for interior furniture), and display evidence of burning. Pottery vessels within the house were expected to have larger diameters than vessels used in typical village contexts in order to contain stored nuts and grains for feasting and village ceremonies. To date, no site in Deep East Texas has been conclusively demonstrated to be the residence complex of a caddi, although Story and Creel (1982) speculated that Area D of Deshazo may have been such a "lesser center" based on the presence of a plaza. Along a similar line, Kleinschmidt (1982) re-evaluated A. T. Jackson's excavation 
of the A. C. Saunders site in Anderson County and presented evidence consistent with Wyckoff and Baugh's xinesi and caddi residence expectations.

While the hypotheses about settlement patterns and material culture described above form the basis for my tentative interpretations of excavation findings at the Tyson Site, practical limitations to applying these models in Deep East Texas must be kept in mind. First, the archaeological database from controlled excavations is relatively limited in the area between the Neches and Sabine River valleys. (The exceptions include Washington Square Mound, Chayah, Mission Dolores, Mission San Jose, Deshazo, Mayhew, and several McGee Bend or Lake Sam Rayburn sites.) Too few sites have been thoroughly excavated to safely assert their degree of community relatedness. The second limitation is the present shaky understanding of local Caddoan culture history. The "Angelina Focus" (Jelks 1965) is often considered to be too "broadly defined" to be of much use (Story 1990:Table 43; Perttula 1992:253). A number of sites within the area, known primarily from surface collected artifacts and excavations at Toledo Bend Reservoir, are said to have affiliations with Frankston, Titus (see Perttula 1993: Fig 2.6.2), and Bossier phases but the boundaries of these cultural units are unknown in the southernmost Caddoan domain. The present uncertainty about culture history and cultural taxonomy probably hints that there may be significant differences between groups of Caddoan people in the past in regard to styles of community hierarchy and settlement pattern. The third significant limitation to the models described here is in our understanding of chronology. There is a paucity of absolute chronometric studies in East Texas apart from the George C. Davis site (Story 1990). The application of ideas developed from 17th-18th century historical accounts and sites may be misleading for interpreting 15 th century Caddoan communities. 


\section{OUTLINE OF TYSON SITE EXCAVATIONS}

The Tyson site (41SY92) is a Caddoan habitation site located on a prominent hill near the confluence of West Creek and Attoyac Bayou in western Shelby County, Texas. The most striking initial impression of the Tyson site is its unusually elevated topographic position. The hill is an erosional remnant of a high terrace rising 25 meters above the eastern floodplain of the Attoyac. The site has a commanding view of the surrounding terrain. Survey of the area has demonstrated the presence of at least five other smaller Caddoan occupation areas (possibly farmsteads) primarily along the margins of lower terraces below the site. While several springs seep from the sides of the hill, the nearest flowing water is 400 meters southwest of the site. The soil at the Tyson site is a moist brown sandy loam (with moderate amounts of limonitic gravel) 50 to 80 $\mathrm{cm}$ thick overlying red and gray mottled clay of the Wilcox formation.

After the site was first identified in November 1991, test excavations were conducted at the Tyson Site on January 25, 1992 by the East Texas Archeological Society (ETAS) and on May 5 and 6, 1992 by students from the Episcopal School of Dallas (under the supervision of Dr. S. Alan Skinner and members of the Dallas Archeological Society). During the 1992 excavations, eighteen test units were opened across the site. A total of $27 \mathrm{~m}^{2}$ was excavated in $15 \mathrm{~cm}$ arbitrary levels; $8.5 \mathrm{~m}^{3}$ of soil were placed through $1 / 4$-inch screen mesh.

July 10 to 18, 1993, the East Texas Archeological Field School was sponsored by ETAS, the Northeast Texas Archeological Society, and the United States Forest Service (USFS), at the Tyson site under the direction of Bob D. Skiles (Archeologist with the USFS). The focus of the 1993 work (Figure 1) was the excavation of a $6 \times 6 \mathrm{~m}$ block (Block 1) and a westward projecting contiguous $12 \times 1 \mathrm{~m}$ trench (Trench 1). The goal was to examine the area around a $1.3 \mathrm{~m}$ wide pit excavated in 1992 . The earlier pit (Feature 3) had contained a large amount of daub, bone, pottery, and chipped stone. It was speculated that Feature 3 was situated inside or very near a burned Caddoan house. 


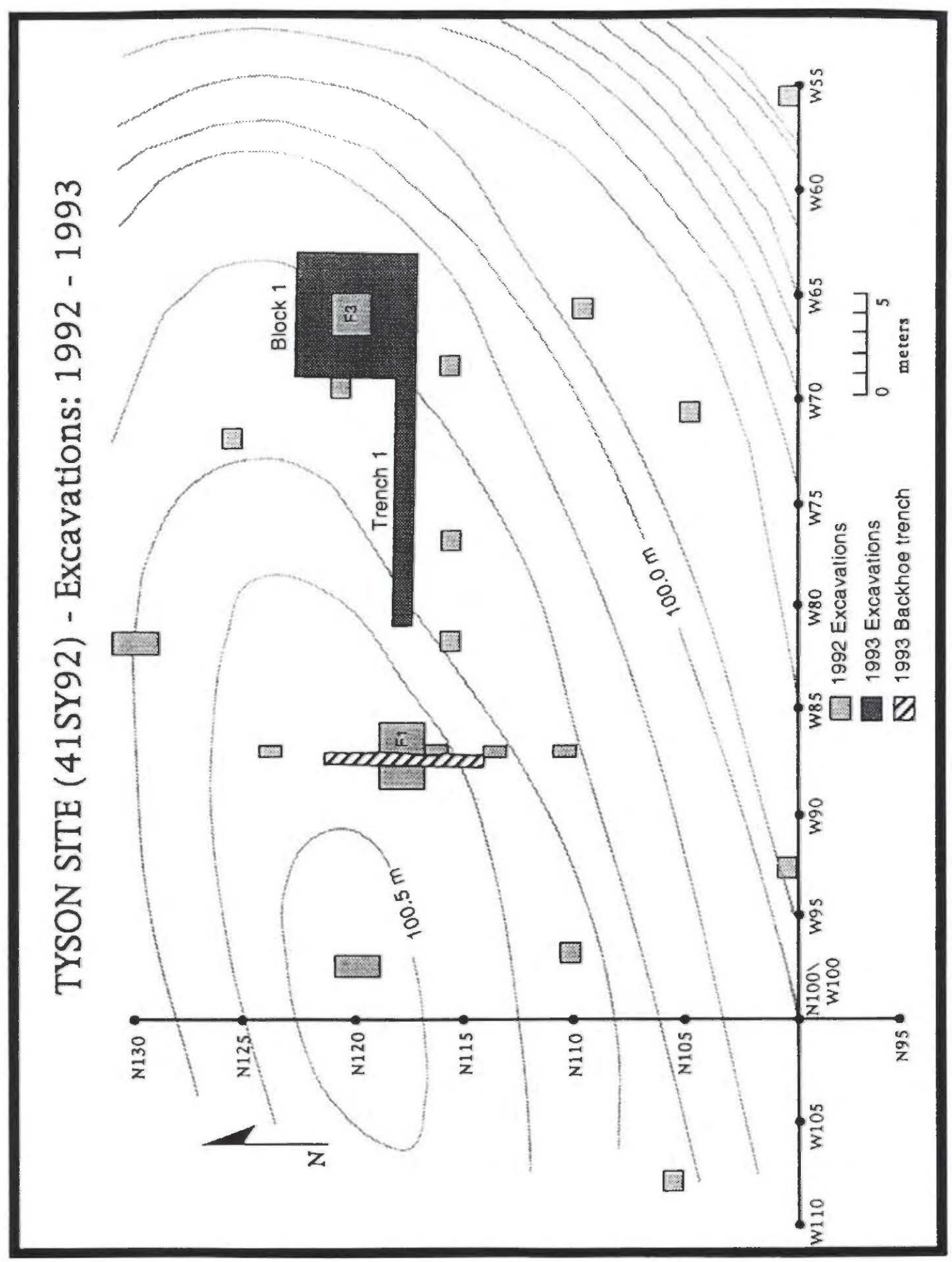

Figure 1. 1992-1993 Excavations at the Tyson Site (41SY92). 
The 1993 Field School plans were to look for evidence of a house and to describe the aboriginal use of this portion of the site. Other research questions posed before beginning the Field School involved matters of paleoenvironment, utilitarian craft activities, subsistence, and cultural affiliation (Middlebrook 1993a). During this most recent field work at Tyson, a total of $44 \mathrm{~m}^{2}$ was excavated in $10 \mathrm{~cm}$ levels; approximately $20 \mathrm{~m}^{3}$ of soil were placed through an 1/8-inch water screen. An additional 1993 task was the examination of a backhoe trench through an anomalous clay feature (Feature 1) partially excavated the year before (see Figure 1).

During excavations at the Tyson site, thirty-three soil disturbances were recorded and examined (although four were not profiled). Of these, eight were found to be of "no cultural significance." The remaining 25 features were designated as follows:

$\begin{array}{ll}\text { Posthole } & \mathrm{n}=14 \\ \text { Possible posthole } & \mathrm{n}=4 \\ \text { Pit } & \mathrm{n}=3 \\ \text { Burial } & \mathrm{n}=2 \\ \text { Clay feature } & \mathrm{n}=1 \\ \text { Rock cluster } & \mathrm{n}=1\end{array}$

\section{The Clay Feature}

During an early excursion to the Tyson site, the author's ten year old son discovered through the use of a soil probe a small area of dense red-orange clay approximately $15 \mathrm{~cm}$ below ground surface. Subsequent investigation of this "clay feature" (Feature 1) revealed a $2.3 \times 1.6 \mathrm{~m}$ subrectangular mass of relatively unmottled clay (which contrasted with deeper "natural" clays) which is oriented roughly east-west in its longest dimension. A profile through Feature 1 displayed a vertical and well defined lateral margin to a depth of $80 \mathrm{~cm}$ at the contact with the underlying clay B-horizon. No 
distinct lower feature margin could be discerned. The feature was covered by a very dark brown sandy loam (midden) plow zone. The upper surface of the clay was distinct but very slightly undulating; no evidence of firing was noted. The clay was devoid of all cultural artifacts but a few bits of organic material were noted in the upper few $\mathrm{cm}$ of the Feature 1. A possible small posthole with a vertically oriented sherd was found in the southwest quadrant of the feature. Three additional postholes were noted just east, southeast, and south of the clay contained within the normal sandy loam of the site.

Raymond Dolezel, a local soil scientist, examined a backhoe trench profile through the clay feature. His conclusion was that Feature 1 could not be natural. $\mathrm{He}$ found evidence of an excavated pit to a depth of approximately $80 \mathrm{~cm}$ in which three different deposits had been placed:

(1) The lower half of the clay was composed of material from the Wilcox clays with inclusions of glauconitic shale from the Weches formation, transported from some distance to the site. Mr. Dolezel commented that this material would have been excellent for pottery making; (2) The upper portion of the clay feature was composed of Wilcox materials but with the addition of sodium salts. Natural saline wells are known from the Flat Fork drainage in northern Shelby County. Striking columnar fracturing of the upper $30 \mathrm{~cm}$ of the clay was thought to be the result of significant weight (or hand packing), or indicative that the clays were originally in solution within the pit; (3) Along the outer margins of the Feature 1, especially beside the basal portion, a fluvial sand was observed with soft manganese-containing masses formed originally in extremely low $\mathrm{pH}$ conditions. This soil was thought to be added to the pit from a stream channel.

Three clay samples were taken from the feature but, as yet, have not been studied by a soil geologist. Dr. Jack Keller, a consultant to the Field School, obtained 12 
magnetic susceptibility samples from the clay feature which have been analyzed in Dr. Michael Collin's lab at the Texas Archeological Research Laboratory (TARL). No culturally relevant discontinuities are evident in the column of samples, although it is possible that magnetic susceptibilities may be higher throughout Feature 1 compared to the surrounding soil profile. Additional comparative column samples will need to be studied in the future to support or refute this speculation.

An archaeological interpretation of the clay feature is not obvious at this point. A plausible explanation is that this clay-filled pit was involved in storage of material for pottery making. Meager support for this notion was the discovery of a burnishing stone adjacent to the feature. But one must wonder why potter's clay would need to be stored in this fashion when clay appears to be readily abundant along the sides of the hill on which the site is located. Was the pit used for some special treatment of the clay? Light may be shed on this problem by comparing the clay mineralogy of the feature to the lump of potter's clay found in Burial 2. An intriguing possibility is that the clay feature was located within a house or other structure as suggested by the postholes nearby; additional investigation of Feature 1 is clearly warranted.

\section{Domestic Features in Block 1}

Eighteen cultural features were noted during excavation of Block 1 and the eastern two units of Trench 1 (Figure 2). While the clear outline of a house wall could not be determined, there is considerable evidence supporting the association of these features with a domicile.

A $1.15 \times 0.9 \mathrm{~m}$ oval hearth (Feature 9) was exposed at $20 \mathrm{~cm}$ depth when excavating the southwestern portion of Block 1. The hearth was slightly basin-shaped and approximately $15 \mathrm{~cm}$ thick. The feature contained large amounts of ash from in situ burning, nuggets of fired clay, a small amount of bone, and several burned sherds with adherent ash. A discontinuous thin layer of bright orange clay near its bottom suggested 


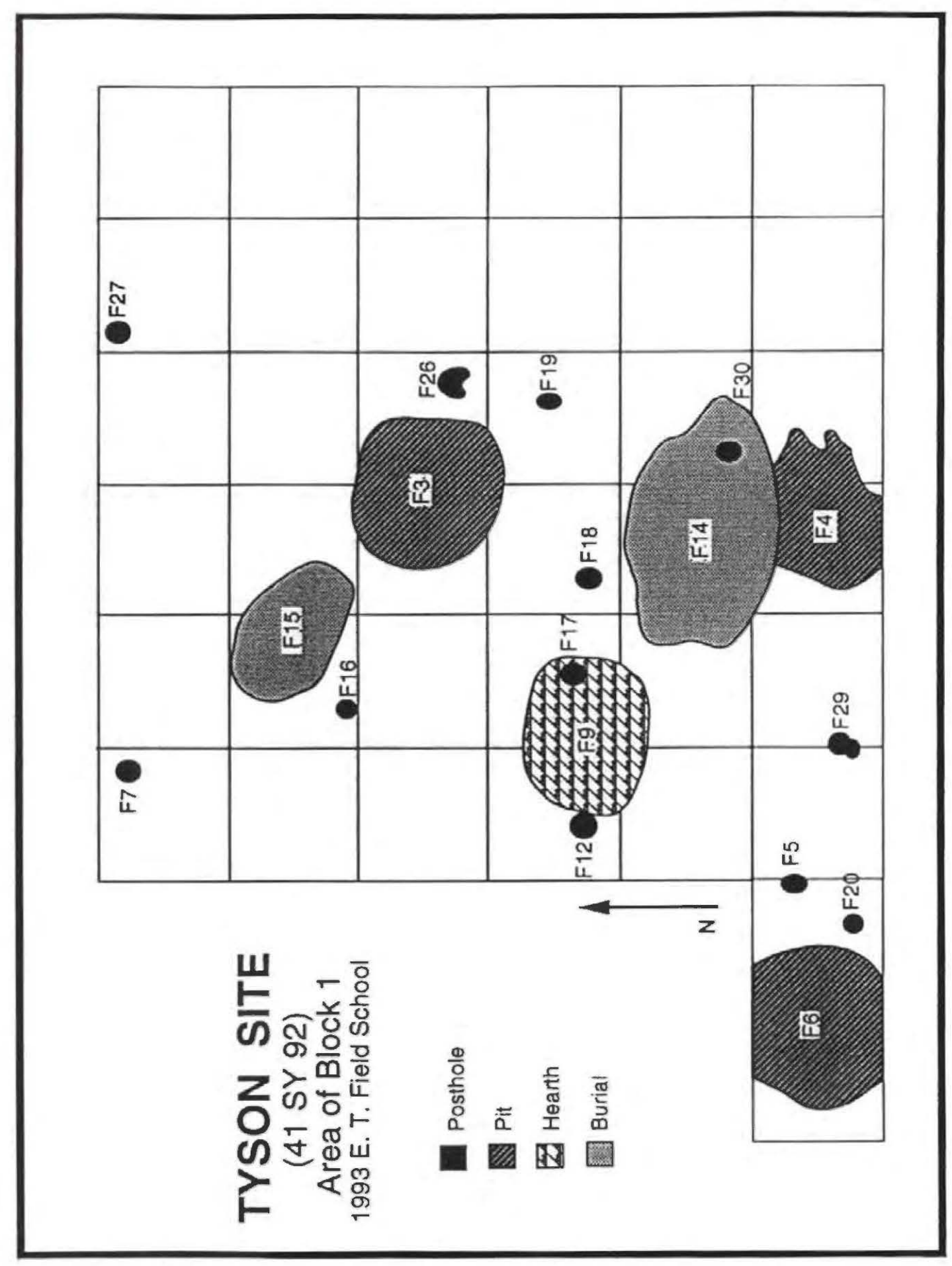

Figure 2. Area of Block 1, 1993 East Texas Field School. 
that the hearth had been prepared for use. Two large postholes were found in the area of Feature 9: Feature 17 was discovered underneath the eastern end of the hearth; it was 30 $\mathrm{cm}$ in diameter and had a smoothly rounded bottom at $75 \mathrm{~cm}$ bs. Feature 12, just west of the hearth, had similar proportions (diameter $27 \mathrm{~cm}$; depth $65 \mathrm{~cm}$ bs).

Does Feature 9 represent the central hearth of a Caddoan house? No answer to this question can be currently given because the outlines of a putative structure in the Block 1 area have not been revealed to date. Early Spanish writers did note the presence of a central fireplace in the caddi's residence, as well as a removable central post in the construction of houses that then became the location of a fire (Wyckoff and Baugh 1980; Newell and Krieger 1949). Fifteen references describing controlled excavations of 53 East Texas Caddoan sites were reviewed to sample information presently available concerning the location of hearths within houses (Story 1972, 1981, 1982; Jelks 1965; Woodall 1969; McClurkan et al. 1966; Anderson et al. 1974; Bruseth and Perttula 1981; Newell and Krieger 1949; Creel 1979; Kleinschmidt 1982; Jones 1968; Corbin et al. 1978, 1980; and Kenmotsu 1992). In these studies, 43 hearths (along with numerous ashfilled pits) were mentioned from 15 sites (Table 1).

All of the "central hearths" in this review were found at the George C. Davis site under Mound A and B and in the village areas. Newell and Krieger (1949:24) noted:

Fireplaces were found in 14 of the 34 (house) outlines, always approximately in the center. . . A large central posthole was present in more than half the outlines, usually at about the center of the fireplace when the latter was present. Some extended through the fireplace, but others had definitely been cut off before the fireplace was made.

The findings at George C. Davis are consistent with observations at some other Caddoan mound sites. For example, Webb (1959) excavated eight houses in two Bossier and Belcher phase mounds at the Belcher site: seven of the eight houses had a central hearth or ash bed; three were clay-lined and one had a central posthole beneath it. 


\begin{tabular}{|c|c|c|c|c|c|c|}
\hline Reference & $\begin{array}{l}\text { Project or } \\
\text { Site }\end{array}$ & $\begin{array}{l}\text { \# of Sites } \\
\text { in Study }\end{array}$ & $\begin{array}{l}\text { \#of Sites } \\
\text { with Hearths }\end{array}$ & $\begin{array}{l}\text { \# of Hearths } \\
\text { in Study }\end{array}$ & $\begin{array}{l}\text { \#of Central } \\
\text { Hearths }\end{array}$ & Notes \\
\hline $\begin{array}{l}\text { Newell \& } \\
\text { Krieger, } \\
1949 \\
\end{array}$ & Geo C Davis & 1 & 1 & 14 & 14 & 34 house patterns \\
\hline Story, 1972 & Geo C Davis & 1 & 1 & 3 & 3 & $\begin{array}{l}\text { I hearth under Mound } 8 \text {, other } \\
2 \text { in ulllage. } 2 \text { of } 3 \text { hearths had } \\
\text { centernosis. }\end{array}$ \\
\hline Story, 1981 & Geo C Dauis & 1 & $\theta$ & $\theta$ & B & $\begin{array}{l}\text { many charcoal filled pits; } \\
\text { F196-11 pit with in silu burning }\end{array}$ \\
\hline Creel, 1979 & Geo C Davis & 1 & 1 & $1(7)$ & 0 & concentration of burned clay \\
\hline Story, 1982 & Deshazo & 1 & 1 & 3 & B & $\begin{array}{l}\text { Hearth } t \text { untikely to be a central } \\
\text { hearth, but possibly the remains of } \\
\text { all night bonfire in "annual renewal } \\
\text { ceremonies. }\end{array}$ \\
\hline Jelks, 1965 & McGee Bend & 13 & $\theta$ & 0 & 0 & $\begin{array}{l}17 \text { pits were recorded from } 6 \text { siles; } \\
9 \text { of these pits contalned some ash } \\
\text { or burned clay }\end{array}$ \\
\hline $\begin{array}{l}\text { Woodall, } \\
1969\end{array}$ & Toledo Bend & 2 & 1 & 5 & 0 & $\begin{array}{l}\text { Bison } 8 \text { had } 5 \text { clrcular charred areas } \\
\text { said to be outdoor hearths }\end{array}$ \\
\hline $\begin{array}{l}\text { Mcclurken } \\
\text { et al, } 1966\end{array}$ & Toledo Bend & 3 & 1 & 2 & $\theta$ & $\begin{array}{l}\text { description of hearths sound more } \\
\text { like trash filled pits }\end{array}$ \\
\hline $\begin{array}{l}\text { Anderson } \\
\text { et al, } 1974\end{array}$ & $\begin{array}{l}\text { Lake } \\
\text { Palestine }\end{array}$ & 10 & $\theta$ & $\theta$ & $\theta$ & Debro site had ash rilled pit \\
\hline
\end{tabular}




\begin{tabular}{|c|c|c|c|c|c|c|}
\hline Reference & $\begin{array}{l}\text { Project or } \\
\text { Site }\end{array}$ & $\begin{array}{l}\text { \# of Sites } \\
\text { In Study }\end{array}$ & $\begin{array}{l}\text { \#of Sites } \\
\text { with Hearths }\end{array}$ & $\begin{array}{l}\text { \# of Hearths } \\
\text { in Study }\end{array}$ & $\begin{array}{l}\text { \# of Central } \\
\text { Hearths }\end{array}$ & Notes \\
\hline $\begin{array}{l}\text { Bruseth \& } \\
\text { Perttula, } \\
1981\end{array}$ & Lake Fork & 9 & $?$ & 9 & $?$ & $\begin{array}{l}\text { Most house patterns near hearths } \\
\text { not discernible }\end{array}$ \\
\hline $\begin{array}{l}\text { Klein- } \\
\text { schmidt, } \\
1982\end{array}$ & A C Saunders & 1 & 1 & 5 & $\theta$ & \\
\hline Jones, 1968 & $\begin{array}{l}\text { "Kinsloe } \\
\text { Focus" }\end{array}$ & 7 & 0 & 0 & 0 & \\
\hline $\begin{array}{l}\text { Corbin } \\
\text { et al, } 1978\end{array}$ & Chaya & 1 & $\theta$ & 0 & 0 & \\
\hline $\begin{array}{l}\text { Corbin } \\
\text { ef al, } 1980\end{array}$ & $\begin{array}{l}\text { Mission } \\
\text { Delores }\end{array}$ & 1 & 1 & 1 & $\theta$ & Feature 6 eroding from ditch \\
\hline $\begin{array}{l}\text { Kenmotsu, } \\
1992\end{array}$ & Maynew & 1 & $\theta$ & $\theta$ & 0 & \\
\hline 15 STUDIES & & 53 & 15 & 43 & 17 & \\
\hline
\end{tabular}


Most of the remaining reports summarized in Table 1 did not demonstrate hearthhouse associations, due primarily to the small areal extent of excavations or other factors that prohibited posthole detection. Where house patterns were defined, only three sites were found to have had hearths away from the house. The Spoonbill site had a hearth $3.75 \mathrm{~m}$ southeast of the center of a circular house, while in the 1930 s five hearths were found in and around the possible "fire temple" at A.C. Saunders. At the Deshazo site, three hearths were uncovered in the vicinity of overlapping structures in Unit 1 . Hearth 2 was likely a small utilitarian fireplace about midway between the center post and the exterior wall. Hearth 3 had a posthole underneath it, but it was not clearly associated with any structure. Hearth 1 , near several central posts, may not have been associated with any of the three houses. Carolyn Good (1982) speculated that this feature may well have represented the locale of an all-night bonfire in the "annual renewal" ceremonies described by early Spanish writers.

In summary, archaeological evidence from East Texas Caddoan sites modestly, but inconsistently, supports the inference that hearths tend to occur in the center of house structures. Nevertheless, major gaps still exist in our understanding of fireplaces. Hearths are not created equal; rather, they vary in size, shape, location, preparation, function, duration of use, and contents. The information in Table 1 regarding Caddoan hearths and houses, due to its skewed nature, has clear limitations when applied to the Tyson site. Nevertheless, a working hypothesis that Feature 9 is a central hearth is appealing because of its large size, its association with large postholes, and its proximity to other likely interior house features. Careful analysis of the faunal, paleobotanical, and ceramic contents of the hearths may reveal more clues about the function of Feature 9.

Located two meters northeast of Feature 9 was Feature 3, a 1.3 m round basinshaped pit $70 \mathrm{~cm}$ in greatest depth (see Figure 2). During early phases of excavation, the large amount of daub in the matrix was impressive; a total of $5,966 \mathrm{~g}$ of daub was collected from the pit. Some of the daub showed evidence of smoothing and possible 
finger impressions (see Webb 1959:59-60). A number of fragments of daub also had leaf impressions (oak, willow, black tupelo, and maple). Additional contents of Feature 3 included bone, charcoal, shell, lithic debitage, eight whole or broken arrowpoints, and 644 ceramic sherds. A large amount of ash and charcoal was noted in the lowest levels of the pit and red and orange burned clay was exposed along the bottom concave surface.

Faunal material from Feature 3 was in excellent condition. This material was analyzed by Brian Shaffer at the University of North Texas. Seventeen hundred and three specimens were recovered, and less than one percent exhibited marked weathering. Burning was noted on 59 percent of the faunal specimens, a relatively high proportion. Based on the lack of extremely small spirally fractured bone and the presence of larger spirally fractured specimens, bone recovered from the Tyson Site appears to have been processed for marrow, but not for grease. Large spirally fractured sections and the presence of dynamic loading impact points on five specimens indicates that the bone was not extensively processed, but simply opened for marrow removal. Eight specimens were identified with cut marks. Five of the specimens had cut marks located in joint areas, as the cuts served to disarticulate the joints. One complete deer ulna bone awl was recovered from Feature 3. Faunal taxa recovered included bowfish, catfish, perch, mud turtle, Eastern box turtle, duck, turkey, passenger pigeon (now extinct), jay, cottontail rabbit, swamp rabbit, squirrel, skunk, raccoon, deer, and bison.

Three radiocarbon samples were obtained from Feature 3 (Middlebrook 1993b); two samples were composed of woody charcoal and the third was a well preserved mussel shell. All samples were submitted to the University of Texas Radiocarbon Laboratory. Routine dates, delta ${ }^{13} \mathrm{C}$ corrections, and dendrochronological calibrations were generated for each sample, and the dendrocalibrated ages are the most accurate. The dates demonstrate remarkable agreement despite the fact that two different carbon sources were utilized; the calibrated charcoal ages were A.D 1418 (TX-7612) and A.D. 1435 (TX-7626) while the calibrated shell age was A.D. 1422 (TX-7625). Some 
caution in interpreting dates for the feature should be used since the contents from which the samples were taken appear to be midden fill and do not represent the products of in situ burning in the pit.

Two additional pits were noted in the area of the hearth. Feature 4 was an irregularly shaped pit, $2.5 \mathrm{~m}$ southeast of Feature 9 , first observed at $40 \mathrm{~cm}$ bs, with associated large sherds, mussel shell, and deer sacrum and antler. This pit was roughly basin-shaped but its bottom was uneven (at $65 \mathrm{~cm}$ bs). Careful excavation revealed that its fill predated the placement of Feature 14 (Burial 1). Feature 6 was located $3 \mathrm{~m}$ southwest of the hearth. The round feature was clearly basin-shaped and extended to 52 $\mathrm{cm}$ bs. The matrix was similar to that of Feature 4, but was more homogeneous than the relatively mottled fill of the burials. Charcoal, lithics, pottery, and bone were scattered through most levels of the pit. In contrast to Feature 3, there was no evidence of burned clay or ash in either pit; daub concentrations were also relatively low.

These three pits appear to serve essentially two different functions: cooking and storage. Feature 3 may initially have been used for the containment of a cooking fire. While such pits may also have been utilized in outdoor cooking areas, placing a fire in a pit inside a house would have protected flammable indoor structures and materials. Feature 3 closely matches Dickens' (1985) description of the "Type 5 feature - cooking pit" in his classification of Southeastern garbage-filled pits. Intentional filling of the pit with household refuse is more clearly evidenced in the case of Feature 3 than the other two pits because of the more numerous large sherds and bones. The last stage of Feature 3 filling apparently occurred after the burning of a house due to the significant accumulation of daub in the upper and mid-levels of the fill. The original use of Feature 4 and Feature 6 is more problematic. Their contents are very similar to the overlying midden soil with the exception of lower amounts of daub. These pits may have been filled prior to house burning. Dickens (1985) referred to such pits as "Type 1 features" and suggested that they may have served to temporarily store hard seeds and nuts. Soil 
samples collected for flotation and subsequent paleobotanical analysis may ultimately resolve the function of these features.

Twelve postholes were found in the Block 1 area (see Figure 2). No structural pattern was discerned after posthole mapping, but all of these features were located in the western two thirds of the block. One posthole (Feature 7) showed evidence of burning in place. This post also displayed a sharply tapered end, leading to the speculation that it may have been "driven into the ground" after an initial hole had been dug for its placement.

Feature 14 (Burial 1) was a large pit containing the remains of a 3 to 4 year old child along with eight ceramic vessels, two large and carefully placed complete paired deer antlers, the femur and tibia of a deer, four round carved shell inlays (possible eye representations), four other shell inlays, two carved bone "ear spools," 32 olivella shell beads, three columnella beads (with rounded ends), two broken shell beads, a large marine pelecypod, a turtle carapace (rattle?), a cache of six mussel shells and three smoothed stones, two pitted stones, a cache of six deer ulna awls and two beaver teeth, and a cache of lithic pebble cores, flakes, preforms, and "shell points."

Deer antler and antler representations are known to have ceremonial significance in important Early Caddoan centers such as Crenshaw (Schambach 1991) and Spiro. The antlers (perhaps a part of a head dress) in Feature 14 were placed inverted over a large engraved carinated bowl which in turn rested on the child's cranium. The shell inlays were primarily distributed near the head of the grave and are similar to the ones recovered from mound centers (e.g., Belcher Mound, Burials 10, 15, 25, 26; Webb 1959) and nonmound sites (e.g., Cedar Grove; Kay 1984; and Sawmill; Jelks 1965). The columnella beads were recovered above the chest area and apparently formed a necklace. These beads are widely distributed in the Caddoan Area and have been recovered from Washington Square Mound (Hart 1982), and with infants from the Walter Bell (Jelks 1965) and McLelland sites (Kelley 1993). The numerous olivella beads were scattered 
over the grave, especially in the region of the legs, suggesting they may have been attached to an article of clothing. While the residents of the Tyson site exploited local mussel shell, they had access to more valuable varieties of marine shell obtained through trade. The two carved bone "ear spool"-shaped objects were clearly not worn as ear spools as they were found close to each other but 25 to $35 \mathrm{~cm}$ south of the right side of the cranium. The presence of a flint knapper's kit (awls, beaver teeth, and lithics) suggests the juvenile was male. Given the arrangement of preserved artifacts in the very large pit, it is very likely that a significant quantity of perishable items was also buried with this child.

Feature 15 (Burial 2) contained the skeleton of a very young, possibly female, infant associated with two brushed/incised ceramic vessels, two columnella beads (with squared ends), a mussel shell, and a large lump of potter's clay. The skeletal material is currently being analyzed at the Bioarcheology Laboratory at Texas A\&M University.

\section{Houses in Block 1}

Was there a house in the Block 1 area? The answer is almost certainly "yes." However, the evidence that would best confirm this, an arc of outside wall postholes, has not been revealed thus far. If the hearth was near the center of a house, and the radius of the structure was greater than $5.5 \mathrm{~m}$, then Block 1 would be almost entirely inside the house. In that case, a house wall was not found in the current investigations. Interestingly, Feature 22 is a posthole found in Trench 1 six meters from Feature 17, the large posthole underneath the hearth. While further excavations would be needed to determine if Feature 22 is part of a $12 \mathrm{~m}$ diameter round structure, evidence for a house in the Block 1 area is summarized here:

1. The concentration of four large features (Features 3, 4, 6, 9) representing domestic cooking and storage facilities is unlikely to be found in an outdoor area.

2. Juvenile burials have been known to be placed in Caddoan housefloors. 
3. The relatively high frequency of postholes without clear pattern within Block 1 is reminiscent of the interior of houses and may represent partitions, support posts, or bed frames.

4. Based on partial analysis, the relative frequency of ceramic artifact categories appears to be different within and outside the hypothesized house. The most striking difference is in the distribution of brushed sherds. Brushing is the most common decorative ceramic treatment at Tyson. "Brushed" accounted for 7.3 percent of analyzed sherds inside the probable house area (all Figure 2 units except for "Feature 3"), 20.4 percent of Feature 3 sherds (from the feature and the $2 \times 2 \mathrm{~m}$ unit over Feature 3), and 19.8 percent of sherds from outside the suspected house (all other Tyson site units). Two findings are striking here. First, brushed sherds are conspicuously less frequent inside the "house" than out. If brushed vessels represented common utilitarian jars, other ceramic vessel types may have been utilized for storage, serving, or cooking inside the house or different activities involving pottery were undertaken inside a house when compared to other parts of the site. Second, the fill of Feature 3 contained a higher proportion of brushed sherds than the rest of Block 1, and was roughly equivalent in frequency to the site as a whole. This finding may be expected if Feature 3 was intentionally filled with garbage following the burning of the house.

A few speculations concerning the sequence of Block 1 cultural features can be made as they relate to house construction, usage, and destruction. One should keep in mind, however, that more than one superimposed house pattern may ultimately be demonstrated in the Block 1 area (e.g., as at Deshazo [Good 1982] and other Caddoan sites). The hypothesized sequence is:

1. The earliest event in this area may have been the construction of a large, round house with central post. 
2. The post may have been removed and a central hearth constructed and used in the same area. Careful excavation of Feature 9 gave no evidence that the underlying post (Feature 17) was ever present during hearth use.

3. Pits (Feature 4 and Feature 6) were then dug into the house floor, only to later fall into disuse and be filled by general midden soil.

4. Burial 1 (Feature 14) was then placed in the floor of the house, crossing the old outline of Feature 4. Interestingly, the Tyson infant burials do not appear to be next to the house wall (as they were at Deshazo) but instead have prominent locations near the presumed center of the house.

5. The house burned. This may have been intentional and related to ceremonial activity following the death of important occupants. The house burning postdated the filling of features $4,6,14$, and 15 as indicated by the low density of daub in the features (no more than might be expected by post-occupational bioturbation). Daub was most concentrated in an area within 2-3 meters of the possible central hearth. A similar finding was noted by Webb (1959) in some of the Belcher site houses.

6. Feature 3, probably a cooking pit, was then filled by debris of the burned house and surrounding midden.

\footnotetext{
ARTIFACTS

The present paper will not give a detailed description of the Tyson site artifacts since their analysis is ongoing. However, a brief discussion of the 222 excavation lots inventoried to date (out of 298 lots) will provide some initial data on them.

Ceramics were divided into two classes: (1) sherds larger than $1.5 \mathrm{~cm}$ in longest dimension, and (2) sherds smaller than $1.5 \mathrm{~cm}$ or highly eroded; these were counted $(n=1770)$ but not subjected to further analysis. A summary of surface treatment of the larger sherds is presented below:
} 


\begin{tabular}{lcl} 
Surface Treatment & Number & Percent \\
Plain sherds & 3015 & 61.1 \\
Brushed sherds & 697 & 14.1 \\
Incised sherds & 366 & 7.4 \\
Punctated sherds & 259 & 5.2 \\
Punctated-Incised sherds & 178 & 3.6 \\
Engraved sherds & 362 & 7.3 \\
Pipe fragments & 34 & 0.69 \\
Other artifacts of clay & 26 & 0.54 \\
\hline Total ceramics (large) & 4837 & 100.0
\end{tabular}

We can make the following observations on the Tyson ceramics:

1. The majority were plain body sherds. While many may be fragments of plain utilitarian jars, a substantial percentage of these sherds were likely from lower sections of decorated bowls and jars. A cursory review of plain rim sherds indicated that many of the represented vessels were plain carinated bowls 18 to $25 \mathrm{~cm}$ in diameter. The rims were commonly straight and direct (to slightly thinned) with flat to slightly rounded lips.

2. Brushing was the most common decoration of Tyson vessels. Rims were commonly horizontally brushed with body sherds displaying vertical to diagonal brush marks. This pattern was similar to Jelks' (1965) description of Broaddus Brushed vessels. The brushed designs graded into parallel incised designs and were apparently made by frayed ends of sticks or combs. A substantial lower portion of a coarsely brushed large utilitarian jar was reconstructed from sherds in Feature 3. Several sherds also display alternating panels of diagonal brushing reminiscent of the herringbone pattern of Pease Brushed-Incised but without the typical intervening applique or row of punctations. Some of the Block 1 sherds initially grouped as brushed are from Belcher Ridged vessels. 
3. At Tyson, punctations were produced using the broken or cut end of small sticks and reeds or by fingernails. They were often crudely made and haphazardly arranged within zones on the vessel rim or in large fields on the lower body of vessels. On punctated-incised sherds, the punctations were variously placed within rectilinear, triangular, or curvilinear zones. These Tyson sherds are similar to Pineland PunctatedIncised designs (Jelks 1965) although this type is far too encompassing to be of much local value. One interesting group of sherds was from a large jar with a "triangular" zoned punctated-incised rim with a body displaying a Sinner Linear Punctated design. A number of incised sherds exhibit the kind of large crosshatching often seen in Maydelle Incised.

4. Engraved ceramics represented about 7 percent of the sample and were slightly more common "inside the house." Ten sherds were from at least two barrel-shaped bottles with a Maddox Engraved design. Five sherds were from Poyner Engraved vessels; scroll motifs were not uncommon.

5. Pipe bowl and stem fragments were remarkably common at the Tyson site. Indeed, the number of pipe sherds $(n=34)$ already inventoried exceeds the total number of long-stem pipe fragments $(n=31)$ from all the McGee Bend sites reported by Jelks (1965). Pipe elements approached 1 percent of all analyzed sherds in Block 1 (excluding Feature 3). All pipe fragments appear to resemble the Haley Variety of the Red River pipe (Hoffman 1967).

Six of the ten mortuary vessels from Burial 1 and 2 were identified with previously described types. Interestingly, although some were small in size, none of the whole ceramics were clearly "miniatures" or displayed evidence for immature craftsmanship as sometimes seen in vessels accompanying juvenile burials. A partial description of each vessel follows:

- B1-V1 Bottle; wide, very slight narrowing neck (toward the top); neck displays wide, horizontal, parallel engraved lines; body shows four repeated vertical 
engraved scrolls with a "cross in circle" central element. Height: $18.0 \mathrm{~cm}$; oral diameter: $6.5 \mathrm{~cm}$; neck length: $8.4 \mathrm{~cm}$. Ripley Engraved.

- B1-V2 Globular jar; narrow but sharply flaring rim; parallel vertical trailing that is lmost identical in appearance to B2-V2. Height: $9.0 \mathrm{~cm}$; oral diameter: 7.6 $\mathrm{cm}$; maximum rim diameter: $9.5 \mathrm{~cm}$. Karnack Brushed-Incised (see Suhm and Jelks 1962: Plate 43c).

- B1-V3 Small, crude "cup-shaped" bowl. Undecorated. Height: $6.2 \mathrm{~cm}$; oral diameter: $9.3 \mathrm{~cm}$. Untyped.

- B1-V4 Shouldered bowl; ten crudely engraved or excised "bars" 1.5-2.0 $\mathrm{cm}$ wide connecting two parallel lines $3.5 \mathrm{~cm}$ apart on the rim. Height: $10.0 \mathrm{~cm}$; maximum oral diameter: $16.9 \mathrm{~cm}$. Untyped.

- B1-V5 Carinated bowl; dark and highly burnished vessel inside and out; engraved design composed of three elements: (a) "half column" with straight or biconcave sides covered by two widely spaced parallel semicircle lines, (b) a "fat" negative S-shaped scroll, and (c) sets of 1 to 4 attaching lines that connect the other two elements to each other or to a basal line; there are nine repetitions of the design and lower basal lines (Figure 3). Height: $11.0 \mathrm{~cm}$; oral diameter: $21.5 \mathrm{~cm}$. Vessel B1-V8 has the same design.

- B1-V6 Crudely made, cup-shaped vessel with slightly convex base; horizontal brushing over the $2.5 \mathrm{~cm}$ wide rim, and vertical brushing over the slightly bulging body. Height: $7-8 \mathrm{~cm}$; oral diameter: $7.0 \mathrm{~cm}$. Broaddus Brushed.

- B1-V7 Beaker-shaped jar with slightly everted rim; horizontal brushing along $1.5 \mathrm{~cm}$ rim with rest of body displaying vertical brushing. Height: $12.5 \mathrm{~cm}$; oral diameter $11.5 \mathrm{~cm}$. Broaddus Brushed.

- B1-V8 Carinated bowl similar to B1-V5 with unpolished surfaces; engraved design is essentially identical with six repetitions of column/semicircle design. Height: 8.5; Oral diameter: $17.0 \mathrm{~cm}$; rim diameter: $4.5 \mathrm{~cm}$. 


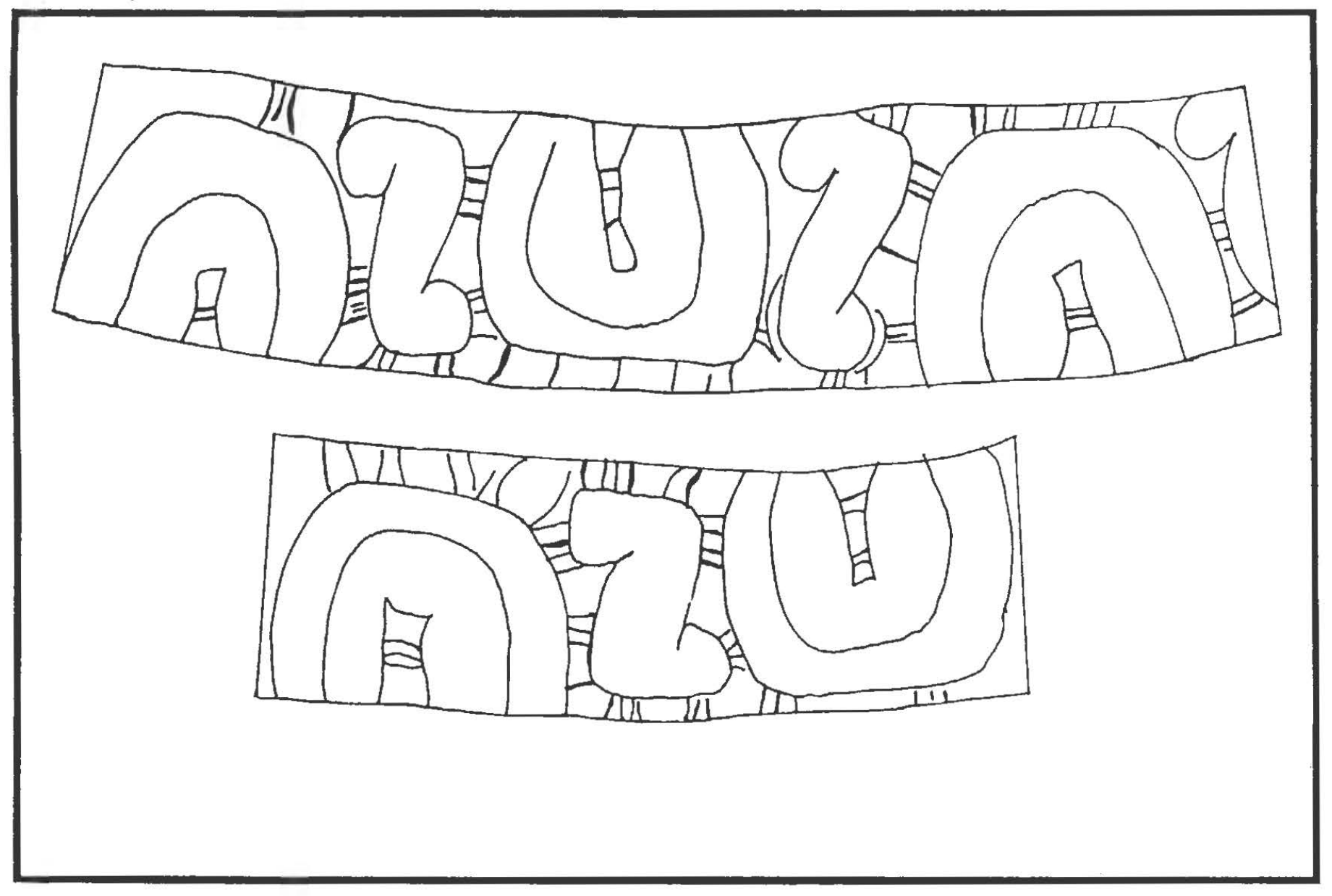

Figure 3. Design from rim of "Tyson Engraved" carinated bowl B1-V5. 
- B2-V1 Cup-shaped vessel with slightly everted rim; "chevron" panels of alternating diagonal incised lines; rim has two rows of small punctations just below lip. Height: $7.5 \mathrm{~cm}$; oral diameter: $7.2 \mathrm{~cm}$; maximum rim diameter: $9.0 \mathrm{~cm}$. Pease BrushedIncised.

- B2-V2 Globular bowl with strongly flaring or everted rim; parallel vertical trailing to $1 \mathrm{~cm}$ below lip; possible red slip on interior of vessel. Height: $8.5 \mathrm{~cm}$; oral diameter: $9.0 \mathrm{~cm}$.; maximum rim diameter: 11.0. Karnack Brushed-Incised.

The two carinated bowls in Burial 1 (B1-V5 and B1-V8) have a distinctive motif first noted at Tyson during the 1992 excavations of Feature 3 when several sherds of two other similar vessels were found. This design has also been identified on bottles from the Hughes site 12 miles east of Tyson and from 41SY45 in northern Shelby county. For convenience, the author is tentatively referring to this engraved motif as "Tyson Engraved." They are carinated bowls, bowls, and bottles from the Shelby County area that have engraved column/semicircles, negative S-shaped scrolls, and attached lines (see Figure 3).

There are several vessels from Deep East Texas which have interesting comparisons to "Tyson Engraved." The reassembled body of a four-cornered bottle covered with "fat" negative S-shaped scrolls from the Blount site is in the TARL collection. Two carinated bowls from 41SY45 have stylized representations of the "column/semicircle" motif without the other components of "Tyson Engraved." Because 41 SY45 probably dates later than Tyson, one might wonder whether this represents local stylistic change in the design.

Lithic analysis is far from complete. A resharpened Dalton point and a Gary-like point were found in controlled excavation but may be unrelated to the Caddo occupation. While approximately 25 arrowpoints, preforms, and other chipped stone tools have been recovered, most are broken and some are remarkably crude. The most frequent arrowpoint types are Perdiz, Bassett, and straight stemmed forms. Lithic debitage is 
composed primarily of small chips from pressure flaking; 85 percent of the raw material is small "creek chert" pebbles, petrified wood fragments, and ferruginous sandstone or hematite. A small amount of lithic material is Edwards chert and other exotic cherts. Approximately 10 pitted stones have been recovered; the only celt from the site was collected from the surface in the 1930s.

Two other artifact groups are noteworthy. One deer bone fragment was recovered with an engraved arrow sign on it. Two very small, clear, blue glass beads with ground ends were also found. These beads are possibly related to a brief Historic Caddo or immigrant Indian group occupation of the Tyson site.

\section{CULTURAL AFFILIATION}

The straightforward association of the Tyson site material culture to a well described or established cultural group is not currently possible. At the outset, there are at least two problems with determining the cultural affiliation of the Tyson site. First, as alluded to previously, there is not an adequate framework for Deep East Texas Caddoan culture history or chronology. A new synthesis of existing data is needed to integrate previous McGee Bend, Washington Square, and Toledo Bend research with a number of other sites known from avocational and cultural resource management work in the region. Developments at the Washington Square mound site from A.D. 1250 to 1350, in particular, may have great significance with respect to defining local cultural traditions. What is presently known from the middle Angelina River drainage suggests, broadly speaking, that a ceramic tradition is present during Middle and Late Caddo periods that is distinct from one seen in Frankston and Allen phases west and north of Bayou Loco (Jelks 1965:270). Pottery decoration in the area emphasizes brushing and punctatedincised designs; often these designs are carelessly made. A few distinctive local designs (Hart 1982), as well as interesting amalgamations and variations on recognizable ceramic types from other areas, are seen in Deep East Texas. Reviewing a number of artifact 
assemblages from the Angelina and Attoyac basins gives the impression that the material culture is complex and bears evidence of broad influences from other areas. Groups of Caddoan peoples may have been culturally diverse, dynamic, and highly interactive. Nevertheless, subdivisions of cultural groups (perhaps reflective of "affiliated groups") may one day be recognizable in individual drainages with more detailed ceramic stylistic analyses.

A second problem in determining the cultural affiliation of Tyson pertains to "diagnostic artifacts." Projectile points are particularly disappointing in aiding group identification due to their scarcity and the notable crudeness of manufacture. Furthermore, recognizable ceramic associations have no clear or predominant pattern in the Tyson assemblage: a Ripley Engraved bottle and two Karnack Brushed-Incised globular bowls are characteristic of the Titus phase; Poyner Engraved sherds are most frequently seen in Frankston phase; Maydelle Incised has been associated with both the Titus and Frankston phases; Sinner Linear Punctated, Maddox Engraved, Belcher Ridged, and Pease Brushed-Incised -like sherds reflect Bossier, Whelan, and perhaps early Belcher phase associations. Finally, the high status artifacts from Burial 1 are not necessarily culturally distinctive, although comparisons with the Belcher site are interesting.

The most obvious Tyson site comparisons must be made with the 13 "Angelina Focus" sites at the McGee Bend Reservoir (Lake Sam Rayburn). While there is a clear overlap in Angelina focus "traits" (see Jelks 1965: 214-215) with the Tyson site material culture, limitations in these comparisons include the multicomponent status and limited excavations of many of the McGee Bend sites. The most significant problem, however, in associating the Tyson site with the Angelina focus is the broad definition given to this cultural unit. Jelks (1965:269) appeared to understand this difficulty: 
An obvious hypothesis--and one that should be tested by additional fieldwork--is that the Angelina Focus spans the time period encompassed by the entire Caddoan sequence. If so, future research may result in fragmenting the Angelina Focus, as it is defined here, into several smaller units.

Is it possible to segregate the Angelina focus into useful (and perhaps more temporally narrow) subdivisions? An initial attempt summarized here yields interesting results. This study began by carefully reviewing data presented in Jelks (1965). Cultural features, projectile point types, and previously defined "diagnostic" ceramic types did not clearly discriminate between different groupings of Angelina Focus sites. Three factors, however, did seem to co-vary: pipe type, percentage of brushed sherds, and the ratio of punctated-incised to brushed sherds (Figure 4).

In order to avoid possible biases due to small sample size, only sites with at least 2500 analyzed sherds were selected for this comparison. In addition to four McGee Bend sites which met this qualification, the Jack Walton site was included because of its proximity to the other sites (Middlebrook 1984). An initial grouping of sites was based upon the long-stemmed versus elbow pipe frequency. This was done as pipe form has been demonstrated by Hoffman (1967) along the Red River to have chronological significance (e.g., elbow pipes replaced earlier long-stemmed pipes). Based on predominant pipe form, the Sawmill and Blount sites were termed "early sites" while Walter Bell, Etoile, and Jack Walton were "late sites." Then these groups were compared along the lines of Jelks' (1965) two newly defined ceramic decorative types; he counted all brushed sherds under the category of Broaddus Brushed and all punctated-incised sherds as Pineland Punctated-Incised without further distinction. To provide more sensitive indicators of relative frequency of these two surface treatments, they are expressed as percentage ratios of: "Pineland/Broaddus". 


\begin{tabular}{|c|c|c|c|c|c|}
\hline \multirow[b]{2}{*}{ SITE } & \multicolumn{4}{|c|}{$\begin{array}{l}\text { COMPARISON OF CERAMIC } \\
\text { ASSEMBLAGES } \\
\text { NGELINA FOCUS SITES WITH } \\
\text { STEM UERSUS ELBOW PIPES }\end{array}$} & \multirow[b]{2}{*}{$\%$ BROADDUS } \\
\hline & LONG STEM & \#ELBOW & \# SHEROS & PINELAND/BRORDDUS & \\
\hline Sawmill & 18 & 4 & 8,650 & .3141 & 10.42 \\
\hline Blount & 7 & 1 & 2,925 & .3645 & 11.18 \\
\hline \multicolumn{6}{|l|}{ TOTAL "EARLY" } \\
\hline Walter Bell & 0 & 3 & 9,239 & .0961 & 21.02 \\
\hline Etoile & 2 & 4 & 4,518 & .1499 & 25.59 \\
\hline Jack Walton & $\theta$ & 4 & 2,914 & .0580 & 21.60 \\
\hline \multicolumn{6}{|l|}{ TOTAL "LATE" } \\
\hline TYSON & 34 & 0 & 4,937 & .2550 & 14.12 \\
\hline
\end{tabular}


This comparison between "early" and " late" Angelina Focus sites suggests consistent differences between groups in terms of major ceramic decorative techniques. Specifically, brushed sherds are less common and punctated-incised sherds are relatively more common in the "early" sites. While the findings from Tyson along these same parameters are intermediate between the two groups, the trends clearly favor its association with the so-called "early" sites (see Figure 4).

The most readily apparent criticism of this simple division of the Angelina Focus sites into "early" and "late" groupings is with the very small number of sites involved. Additionally, the temporal referent for the groups is somewhat presumptuous since a detailed seriation has not been undertaken and the only absolute chronometric dates are from Tyson; furthermore, the significance of geographical variation has not been taken into consideration. Keeping these major problems in mind, Angelina Focus subdivisions proposed here should provide testable hypotheses for future research in the area:

Early Angelina Sites:

- Predominance of long-stemmed pipes

-10-15 percent of sherds display brushing

- Brushed sherds are 3 to 4 times more common than punctated-incised sherds

- Examples: Blount, Sawmill, Tyson

Late Angelina Sites:

- Predominance of elbow pipes

- 20-25 percentof sherds display brushing

- Brushed sherds are 6 to 20 times more common than punctated-incised sherds

- Examples: Walter Bell, Etoile, Jack Walton 


\section{DISCUSSION}

The interpretation of Tyson site findings is tentative and somewhat speculative at this point. The most conservative observation is that Tyson is an early 15 th century Caddoan habitation site. But what were the aboriginal peoples doing here? How did this occupation fit into an overall settlement pattern? Were there any special functions of social, political, or religious life undertaken here?

A few of Wyckoff and Baugh's (1980) predictions concerning the "caddi residence complex" are met at Tyson. Their general descriptions of size and location are congruent with the fact that the site is roughly 2 to 3 acres in size and is located near the center of an occupied river basin. Tyson is also adjacent to the confluence of Attoyac Bayou and a major tributary. Access to the site would have been easy from several different directions. Depending on what the forest vegetation would have been, any caddi at Tyson would likely have been able to see a number of different farmsteads and settlements from the dominating vantage point atop a hill; Tyson is atypical for Deep East Texas Caddoan sites because it is not located on a low rise or terrace just above a floodplain.

Currently, not enough of the site has been explored to ascertain whether a plaza, visitor's house, attendants' house, or cemetery are present as expected at a caddi residence. However, if Block 1 is located inside a large house, then support for a central hearth and "numerous small, interior postmolds on one side of the structure" will have been demonstrated.

While no other predictions made by Wyckoff and Baugh (1980) have been confirmed at Tyson, several additional findings suggest that it is a ceremonial or other special function site:

1. Mortuary associated artifacts in juvenile Burial 1 are numerous, elaborate, and apparently of high status. Some of the artifacts are valuable jewelry or clothing that would have been traded from the coast (e.g., columnella and olivella beads). Other 
materials suggest that the very young child was in need of extensive (e.g., eight pottery vessels) and non-age appropriate provisions in the afterlife (e.g., a large lithic tool making kit). There may have been ceremonial or religious reasons for the inclusion of knapping equipment in this burial; it is difficult to argue that a three to four year old would have been a proficient flintknapper. Some of the artifacts appear to have had purely symbolic meaning (e.g., deer antlers, rattle, earspool-like artifacts, and shell inlays). The only reasonable interpretation of Burial 1 is that the individual was an offspring of a very important person or was a high ranking person is his own right (e.g., a caddi, "heavenly child", etc.).

2. Large amounts of daub and a charred post indicate that a burned house was located in the area of Block 1. While houses may have burned accidentally in any Caddoan community, intentional burning of the residence of religious figures following their death was apparently widespread in the Caddoan Area. In this context, it may be important to note that the house burning post-dated the interment of the children in Burials 1 and 2; the actual amount of time between the two events is unknown, however.

3. The aboriginal clay feature (Feature 1) is unusual for known Caddoan sites, and its origin and function remains puzzling. Until this feature is better understood, its presence at Tyson only buttresses the conclusion that the site is not a typical farmstead or hamlet.

4. The presence of the distinctive ceramic engraved motif at the site, herein tentatively referred to as "Tyson Engraved," suggests that this design may have had special meaning for the site's occupants. There is little question that whomever lived at Tyson had some preference for the motif; it was one of the most common engraved types in the Block 1 area and two bowls bearing the design were placed near the head of the Burial 1 child. The position of Vessel 5 between the cranium and two antlers was certainly not by chance. The hypothesis that this engraved style was a marker for Tyson ceremonial beliefs might be profitably tested in the future. 
5. Pipes are commonly found in Caddoan village sites (Hoffman 1967). The striking finding from the Tyson site is that 34 pipe fragments have already been recovered from the site. This is far out of proportion to the number of pipes found at other Deep East Texas sites. While the possibility exists that the residents of Tyson simply enjoyed the everyday smoking of tobacco, the high frequency of pipe fragments also suggests that the use of pipes denotes ceremonial or "high status" activities. Wyckoff and Baugh (1980:Tables 2 and 4) list a number of European chroniclers' references to pipes and tobacco among the Caddo governing elite:

(a) Joutel 1687; Cahinnio elders held calumet ceremony with French;

(b) Casanas 1690-91; caddi had tobacco pouch and pipe; canahas prepared peace pipe for the caddi;

(c) Espinosa 1715; Spanish smoked feathered peace pipe with Assinais captains;

(d) Espinosa 1716; tamma delivered first ripe tobacco to Captain;

(e) Espinosa 1715-17; xinesi maintained fire temple in which he had tobacco and peace pipe;

(f) Espinosa 1715-17; priests, captains, and old men smoked pipes in harvest ceremony at captain's house;

(g) La Harpe 1719; Nadaco and Naouydiche chiefs smoked calumet with French; and

(h) Aguayo 1721; Neches chief smoked peace pipe with Spanish.

Summarizing the above, a tentative interpretation of the Tyson excavations is that the site is the residence location of an important local Caddoan political or religious figure during the early 15 th century with cultural ties to peoples occupying early "Angelina Focus" sites. Much of the theoretical basis for this interpretation is generated from ethnohistorical and archaeological data derived from Caddoan life 150 to 200 years after Tyson was occupied. Dangers abound in attempting fanciful imposition of models 
of later settlement patterns and social organization onto meager information from a single site in an relatively unknown drainage. The goal of this update, however, is to encourage ongoing thinking and discussion about Deep East Texas archaeological findings and how they fit into the wider Caddoan cultural framework.

\section{REFERENCES CITED}

Anderson, K. M., K. Gilmore, O. F. McCormick III, and E. P. Morenon

1974 Archaeological Investigations at Lake Palestine, Texas. Contributions in Anthropology 11. Department of Anthropology, Southern Methodist University, Dallas.

Bruseth, J. E., and T. K. Perttula

1981 Prehistoric settlement patterns at Lake Fork Reservoir. Texas Antiquities Committee, Texas Antiquities Permit Series, Report no. 2. Texas Antiquities Committee, Austin, and Southern Methodist University, Dallas.

19911991 Field School will be at the Sam Kaufman Site, Red River County, Texas. Texas Archeology 35 (2): 4, 13-14, 19.

Corbin, J. E., J. M. Studer, and L. Nummi

1978 The Chayah Site. Papers in Anthropology No. 1. Stephen F. Austin State University, Nacogdoches.

Corbin, J. E., A. Kalina, and T. C. Alex

1980 Mission Dolores de los Ais, Archaeological Investigations of an Early Spanish Colonial Mission, San Augustine County, Texas. Papers in Anthropology No. 2, Stephen F. Austin State University, and Texas Antiquities Permit Series, Report No. 3, Texas Antiquities Committee, Nacogdoches and Austin.

Creel, D. G.

1979 Archeological Investigations at the George C. Davis Site, Cherokee County, Texas, Summer 1978. Texas Antiquities Permit Series, Report No. 1. Texas A\&M University, College Station and Texas Antiquities Committee, Austin.

1993 An Overview of Investigations at the Hatchel - Mitchell Site Complex, Bowie County, Texas. Paper presented to the 64th Annual Meeting of the Texas Archeological Society, October 31, 1993. Laredo, Texas.

Dickens, R. S., Jr.

1985 The Form, Function, and Formation of Garbage-filled Pits on Southeastern Aboriginal Sites: An Archaeobotanical Analysis. In Structure and Process in Southeastern Archaeology, edited by R.S. Dickens, Jr. and H. Trawick Ward, pp. 34-59. The University of Alabama Press, University, Alabama.

Good, C. E.

1982 Analysis of Structures, Burials, and other Cultural Features. In The Deshazo Site, Nacogdoches County, Texas, Volume 1, edited by Dee Ann Story, pp 51-112. Texas Antiquities Permit Series, Report No. 7. Texas Antiquities Committee, Austin. 
Hart, J. P.

1982 An Analysis of the Aboriginal Ceramics from the Washington Square Mound Site, Nacogdoches County, Texas. Master's thesis, Northeast Louisiana University, Monroe.

Hoffman, M. P.

1967 Ceramic Pipe Chronology along the Red River Darianage in Southwestern Arkansas. The Arkansas Archeologist 8(1):4-14.

Jelks, E. B.

1965 The Archeology of the McGee Bend Reservoir, Texas. Ph.D. Dissertation, Department of Anthropology, University of Texas, Austin.

Jones, B. C.

1968 The Kinsloe Focus: A Study of Seven Historic Caddoan Sites in Northeastern Texas. Master's thesis, Department of Anthropology, University of Oklahoma, Norman.

Kay, M.

1984 Late Caddo Subtractive Technology in the Red River Basin. In Cedar Grove: An Interdisciplinary Investigation of a Late Caddo Farmstead in the Red River Valley, edited by Neal Trubowitz, pp174-206. Research Series 23. Arkansas Archeological Survey, Fayetteville.

Kelley, D. B.

1993 The McLelland and Joe Clark Sites: Protohistoric and Historic Caddoan Farmsteads in Southern Bossier Parish, Louisiana. Coastal Environments, Inc., Baton Rouge. Review draft.

Kenmotsu, N. A.

1992 The Mayhew Site: A Possible Hasinai Farmstead, Nacogdoches County, Texas. Bulletin of the Texas Archeological Society 63:135-174.

Kleinschmidt, U. K. W.

1982 Review and Analysis of the A.C. Saunders Site, 41AN19, Anderson County, Texas. Master's thesis, Department of Anthropology, University of Texas, Austin.

McClurkan, B.B., W.T. Field, and J.N. Woodall

1966 Excavations in Toledo Bend Reservoir, 1964-1965. Papers of the Texas Archeological Salvage Project No. 8, Texas Archeological Salvage Project, University of Texas, Austin.

Middlebrook, T. A.

1984 Test Excavations at the Jack Walton Site 41SA135, San Augustine County, Texas. Paper presented to the 26th Annual Caddo Conference, March 10, 1984, Nacogdoches, Texas.

1993a Field Guide: The 1993 East Texas Archeological Field School. East Texas Archeological Society, Nacogdoches.

1993b Radiocarbon Dates from the Tyson Site (41SY92). Caddoan Archeology Newletter III (4): 2-8. 
Newell, H. P. and A. D. Krieger

1949 The George C. Davis Site, Cherokee County, Texas. Memoir 5. Society for American Archaeology.

Perttula, T. K.

1992 "The Caddo Nation": Archaeological and Ethnohistoric Perspectives. University of Texas Press, Austin.

1993 Historic Context: Effects of European Contact on Native and Immigrant Indians in Northeast Texas, A.D. 1540 -1859. In Archeology in the Eastern Planning Region, Texas: A Planning Document, edited by Nancy Adele Kenmotsu and Timothy K. Perttula, pp. 147-187. Cultural Resource Management Report 3. Department of Antiquities Protection, Texas Historical Commission, Austin.

Schambach, F. F.

1982 The Archeology of the Great Bend Region in Arkansas. In Contributions to the Archeology of the Great Bend Region, edited by Frank F. Schambach and Frank Rackerby, pp. 1-11. Research Series 22. Arkansas Archeological Survey, Fayetteville.

1991 The Crenshaw Site. Presentation to the Texas Archeological Society Annual Field School, June, 1991, Idabel, Oklahoma.

Story, D. A.

1972 A Preliminary Report of the 1968, 1969, and 1970 Excavations at the George C. Davis Site, Cherokee County, Texas: A Report of Field Research Conducted under National Science Foundation Grants (GS2573 and 3200) and Interagency Contracts between University of Texas at Austin and Texas Building Commission and the Texas Historical Committee.

1990 Culture History of the Native Americans. In The Archeology and Bioarcheology of the Gulf Coastal Plain, by D. A. Story, J. A. Guy, B. A. Burnett, Jerome C. Rose, M. D. Freeman, D. G. Steele, B. W. Olive, and K. J. Reinhard, pp. 163-366. Research Series 38. Arkansas Archeological Survey, Fayetteville.

Story, D. A. (Editor)

1981 Archeological Investigations at the George C. Davis Site, Cherokee County, Texas: Summers of 1979 and 1980. Occasional Paper 1. Texas Archeological Research Laboratory, University of Texas at Austin.

1982 The Deshazo Site, Nacogdoches County, Texas, Vol 1. Texas Antiquities Permit Series, Report No. 7. Texas Antiquities Committee, Austin.

Story, D. A. and D. G. Creel

1982 The Cultural Setting. In The Deshazo Site, Nacogdoches County, Texas, Vol 1, edited by D. A. Story, pp. 20-34. Texas Antiquities Permit Series, Report No. 7, Texas Antiquities Committee, Austin.

Suhm, D. A. and E. B. Jelks

1962 Handbook of Texas Archeology: Type Descriptions. Texas Archeological Society Special Publication 1 and Texas Memorial Museum Bulletin 4. 
Trubowitz, N. L. (Editor)

1984 Cedar Grove: An Interdisciplinary Investigation of a Late Caddo Farmstead in the Red River Valley. Research Series 23. Arkansas Archeological Survey, Fayetteville.

Webb, C. H.

1959 The Belcher Mound, a Stratified Caddoan Site in Caddo Parish, Louisiana. Memoir 16. Society for American Archaeology.

Wedel, M. M.

1978 LaHarpe's 1719 Post on the Red River and Nearby Caddo Settlements. Museum Bulletin 30. The Texas Memorial Museum, University of Texas at Austin.

Woodall, J.N.

1969 Cultural Ecology of the Caddo. Ph.D. Dissertation, Department of Anthropology, Southern Methodist University, Dallas.

Wyckoff, D. G., and T. G. Baugh

1980 Early Historic Hasinai Elites: A Model for the Material Culture of Governing Elites. Midcontinental Journal of Archeology 5:225-288. 